\title{
ALGEMEENE VERGADERING.
}

GEHOUDEN 23 FEBRUARI 1884.

Tegenwoordig de leden van het Bestuur: de heeren Kern (Voorzitter), Kniphorst (Penningmeester), Wijnmalen (Secretaris), Quarles van Ufford, Matthes, Humme en van Deventer; voorts de leden: van Alphen, J. H. de Groot, Corns. de Groot, W. van Goltstein, Boele van Hensbroek, Lasonder, van der Stok en Semmelink.

$\mathrm{Na}$ opening der Vergadering heet de Voorzitter de leden welkom, waarna, op zijne uitnoodiging, de Secretaris de notulen voorleest van het verhandelde in de vorige Algemeene Vergadering van 24 Februari 1883; bereids door het Bestuur vastgesteld, worden zij, daar niemand daartegen bedenking oppert, definitief goedgekeurd.

De Voorzitter stelt aan de orde de behandeling van de rekening en verantwoording van den Penningmeester over het dienstjaar 1883, waaromtrent medegedeeld wordt dat zij, na door het Bestuur te zijn nagezien, in handen is gesteld geworden van eene Commissie van twee gewone leden, zijnde de heeren van Goltstein en J. H. de Groot, ten einde daaromtrent der Algemeene Vergadering te dienen van bericht en raad.

Namens die Commissie brengt eerstgenoemde verslag uit van haar onderzoek. Zij heeft, voorgelicht door den Penningmeester, al de bescheiden nauwkeurig nagegaan, en het beheer der kas in de beste orde bevonden, waarom zij dan ook geenszins aarz voor te stellen, de rekening en verantwoording over 1583 goed te keuren en den Penningmeester te déchargeeren, onder dankbetuiging voor zijn beheer.

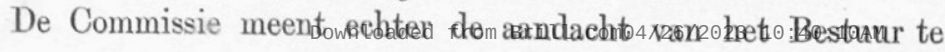


moeten vestigen op het feit, dat eene vergelijking der balans aantoont dat er met betrekking tot het huis geene jaarlijksche afschrijving, bijv. van 5 pCt., plaats heeft, hetgeen, naar men meent, ook elders geschiedt.

De Penningmeester, hierna het woord nemende, doet in de eerste plaats de volgende financieële mededeelingen.

$1^{0}$. De Ontvangsten ad $f$ 9992.475.

Laat men de posten, waarop bij de begrooting niet werd gerekend, achterwege als: toevallige baten tot een bedrag van $f 51.35$, het batig slot der rekening en verantwoording over ' 82 ad $f 261.945$ en de gelden verkregen door den verkoop van drie pandbrieven Nat. Hypotheekbank tot een bedrag van $f$ 2936.25, dan hebben de werkelijke ontvangsten $f$ 944.93 meer bedragen, dan werd geraamd.

Hoofdzakelijk heeft tot dit gunstig resultaat medegewerkt het uit Indië vlugger remitteeren van de aldaar geïnde contributiën. $\mathrm{Na}$ aftrek der onvermijdelijke kosten voor incasseeren en disconto, kon hiervoor in ontvang worden gebracht $f$ 1704.64, dat is $f$ 442.64 meer als waarop, ongeacht de uitgaven van Commissarissen aldaar, die op $f 100$ mindeı waren geraamd, bij de begrooting werd gerekend 1. Wijders was nog van invloed, een hoogere opbrengst van contributiën in Nederland tot een bedrag van $f 220.50$; meerdere geïnde, rente ad $f 99.35$ en een hoogere opbrengst van het boekenfonds tot een bedrag van $f$ 182.44.

20. De Uitgaven ad $f$ 9724.985. Deze hebben $f$ 3926.98s meer bedragen dan werd geraamd. Trekt men hiervan echter af een bedrag van $f 2507.375$, dat ter aflossing der hypotheek meer werd uitgegeven dan waarop in de begrooting werd gerekend, dan wordt de overschrijding der begrooting al dadelijk tot het cijfer van $f 1419.61$ teruggebracht.

Onder de overige tien posten die overschreden werden, komt aan de drie posten: gewone drukwerken, buitengewone drukwerken en subsidieeren of uitgeven van afzonderlijke werken het leeuwenaandeel toe. Alleen deze drie posten werden tot het bedrag van $f 2287.52$ overschreden en de overige zeven met $f 139.75^{5}$ of te zamen $f 2427.27 \mathrm{~s}$.

1 Hierdoor werd nog maar gedeeltelijk ingehaald het bedrag ad $f$ 1085.70, dat, blijkens de toelichting op de rek, en verantw. van 1882, Indië dat jaar op de raming is achtergebleven.

4e Volgr. VIII. 
Daarentegen werd op tien andere posten niet onbelangrijk bezuinigd: o. a. onderhoud gebouw, verwarming lokalen, honorarium, enz. enz. en dit wel tot een bedrag van $f 1007.66^{5}$.

Hierdooor wordt dan ook de overschrijding teruggebracht tot de reeds genoemde som van $f$ 1419.61, terwijl de Rekening en Verantwoording nog met een batig saldo van $f 267.49$ is afgesloten kunnen worden.

30. Het Aflossingsfonds.

Het onvereffende bedrag der hypotheek was op ult. December 1882 nog groot $f$ 3000.-

Het batig slot over dat jaar bestemd voor het aflossingsfonds was groot $f 261.945$, terwijl als gewoonlijk voor dat doel op de begrooting was uitgetrokken een som van $f 500$ of te zamen $f$ 761.945. In de 241 ste Bestuursvergadering werd intusschen besloten tot de geheele aflossing der hypotheek over te gaan.

Ter voldoening hiervan werden drie pandbrieven Nat. Hypotheekbank te gelde gemaakt en hiervan $f 2238.005$ voor aflossing aangewezen.

Hiermede nu is het Instituut, zooals ook reeds in het Verslag door den Secretaris werd opgemerkt, in het vrije bezit van een eigen haard gekomen.

40. De Balans.

Omtrent de activa valt op te merken, dat het op ult. ' 82 in kas zijnde geldswaardig papier tot aflossing der hypotheek en tot dekking der overschreden begrooting is te gelde gemaakt.

De bibliotheek en handschriften en het boekenfonds zijn dit jaar, de eerste wegens uitbreiding en de tweede wegens belangrijke aanwinsten ten gevolge van de uitgaven van vier feestgaven ter gelegenheid van het 6e Orientalisten Congres, respectievelijk met $f 200$ en $f 500$ verhoogd.

De waarde van den inboedel op ult. ' 82 getaxeerd $f 2099.50$, is met 5 pCt. verminderd en nu genoteerd op $f$ 1994.525, terwijl de door M. Nijhoff in 1883 reeds verkochte en nog te verkoopen boeken, even als vroeger weder pro memorie zijn opgebracht.

Omtrent de passiva valt op te merken dat door de aflossing der hypotheek zij tot nihil zijn gereduceerd en dus de activa ad $f 45,262.01^{5}$ den financieëlen toestand van het Instituut aanwijzen op ult. December 1883. 
Op de vorige balans op ult. Dec. 1882 overschreden de Activa de Passiva met

$f 44,636.44^{5}$

en thans op ult. Dec. wordt die post vertegenwoordigd door .

$45,262.01^{5}$

zoodat dan ook de bezittingen van het Instituut nog zijn vooruitgegaan met een som van $f \quad 625.575$

De opmerking van de Commissie beantwoordende omtrent de niet plaats gehad hebbende afschrijuing van de waarde van het huis, herinnert de Penningmeester, dat hij in deze niet mocht afwijken van het in het vorige jaar door het Bestuur genomen besluit, waarbij bepaald werd, dat er geene jaarlijksche geregelde afschrijving zou geschieden.

De Voorzitter dankt den Pemningmeester voor zijn uitvoerige mededeelingen, en stelt in de eerste plaats de behandeling voor van de conclusie der Commissie, belast met het onderzoek der rekening.

Daar niemand daarover het woord verlangt, wordt zij, zonder hoofdelijke stemming, onder toejuiching goedgekeurd, waarna de Voorzitter den Penningmeester den dank der Vergadering aanbiedt voor de vervulling zijner taak.

Wat de door de Commissie medegedeelde opmerking betreft, daarover voeren achtereenvolgens het woord de hh. Humme, Corn. de Groot en de Voorzitter, die er op wijzen, dat de gevorderde afschrijving van de waarde van het huis geen algemeene regel is, terwijl de zaak zelve geenszins van zulk een overwegend belang te achten is, dan dat men haar niet veilig ter verdere afdoening zou kunnen stellen in handen van het Bestuur, waartoe dan ook de Voorzitter het voorstel doet.

Dienovereenkomstig wordt eenparig besloten.

De Vergadering gaat hierna over tot het verkiezen van vier Bestuursleden ter vervulling der vacatures, ontstaan door de aftreding der hh. Juynboll, Kniphorst en Quarles van Ufford en door het overlijden des heeren van Musschenbroek, en waarvoor de Voorzitter de door het Bestuur volgens art. 6, al. 3 van het Reglement opgemaakte drietallen mededeelt.

Tot stemopnemers worden benoemd de hh. Boele van Hensbroek en Semmelink, die, na eene pauze, mededeelen, dat de uitslag der stemming is, dat met groote meerderheid van stemmen

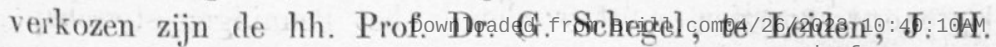


de Groot, te 's Gravenhage, P. J. B. C. Robidé van der Aa, mede te 's Gravenhage, en G. A. Wilken, te Leiden.

Ter vergadering tegenwoordig, verklaart de heer De Groot, naar aanleiding der door den Voorzitter tot hem gerichte vraag, zich bereid de benoeming te aanvaarden, terwijl aan de drie andere benoemden van hunne verkiezing zal worden kennis gegeven.

De Voorzitter dankt de stemopnemers voor de door hen genomen moeite en betuigt tevens aan de aftredende Bestuurders de erkentelijke gevoelens der instelling voor de trouwe behartiging harer belangen.

De Secretaris brengt vervolgens, uit naam van het Bestuur, verslag uit nopens den staat en de werkzaamheden van het Instituut over 1883.

Overeenkomstig het voorstel des Voorzitters wordt bosloten het Verslag als naar gewoonte in de Bijdragen op te nemen (zie blz. LXVI en vlg.), terwijl de Vergadering zich, door toejuichingen, vereenigt met den dank, welken den Voorzitter den Secretaris voor de vervulling zijner taak aanbiedt.

De Secretaris deelt der Vergadering mede, aan welke personen het Bestuur in zijne jongste Bestuursvergadering heeft besloten het lidmaatschap aan te bieden. (Zie de notulen der Bestuursvergadering van 16 Februari jl.).

Niets meer hierna aan de orde zijnde, wordt de Vergadering gesloten.

249ste (BUTTENGEWONE) BESTUURSVERGADERTNG.

GEHOUDEN 23 FEBRUARI 1884.

Tegenwoordig de hh. Kern (Voorzitter), van Deventer, Humme, Niemann, Matthes, de Groot en Wijnmalen (Secretaris).

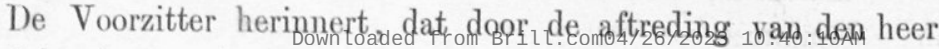
Kniphorst voorzien moet worden in het Pennrïngifięesterschap, 